\title{
Genotypic variability in Populus tremula $L$. affects how anthropogenic nitrogen enrichment influences litter decomposition
}

\author{
Franziska Bandau (D) - Benedicte Riber Albrectsen • \\ Riitta Julkunen-Tiitto • Michael J. Gundale
}

Received: 29 January 2016 / Accepted: 19 August 2016/Published online: 8 September 2016

(C) The Author(s) 2016. This article is published with open access at Springerlink.com

\begin{abstract}
Background and aims Boreal forests can receive substantial nitrogen $(\mathrm{N})$ enrichment via atmospheric $\mathrm{N}$ deposition and industrial forest fertilization. While it is known that $\mathrm{N}$ enrichment can impact ecosystem properties, such as litter decomposition, it remains poorly understood how genetic variability within plant species modifies these impacts.

Methods We grew replicates of ten Populus tremula L. genotypes (GTs) under $3 \mathrm{~N}$ conditions; ambient, and levels representing atmospheric $\mathrm{N}$ deposition and industrial forest fertilization. We measured leaf and litter physical and chemical traits, and conducted a litter decomposition assay.

Results Leaf traits varied due to N treatment, GT, and constitutive tannin levels. Leaf traits were in some cases correlated with litter traits, and decomposition was
\end{abstract}

Responsible Editor: Alfonso Escudero.

Electronic supplementary material The online version of this article (doi:10.1007/s11104-016-3033-8) contains supplementary material, which is available to authorized users.

F. Bandau $(\bowtie) \cdot$ B. R. Albrectsen

Department of Plant Physiology, Umeå Plant Science Centre, Umeå University, SE 90187 Umeå, Sweden

e-mail: franziska.bandau@umu.se

R. Julkunen-Tiitto

Department of Biology, Natural Product Research Laboratory, FI 80101 Joensuu, Finland

\section{J. Gundale}

Department of Forest Ecology and Management, Swedish University of Agricultural Sciences, SE 90183 Umeå, Sweden influenced by single and interactive effects of $\mathrm{N}$ and GT. Nitrogen addition unexpectedly decelerated decomposition, potentially due to changes in specific leaf area (SLA). Variation in decomposition rates among the GTs was best explained by their differences in SLA, and lignin: $\mathrm{N}$ ratio. Nitrogen addition also caused a shift in which traits most strongly influenced decomposition. Conclusions Our findings highlight that the considerable diversity present in tree species can have a strong influence on ecosystem processes, such as decomposition, and how these processes respond to environmental change.

Keywords Aspen - Condensed tannins - Genotypic variation · Genotype-environment interaction · Mass loss $\cdot$ Nitrogen enrichment

$\begin{array}{ll}\text { Abbreviations } \\ \text { N } & \text { Nitrogen } \\ \text { GT(s) } & \text { genotype(s) } \\ \text { GDBH } & \text { growth differentiation balance hypothesis } \\ \text { Tgr(s) } & \text { tannin group(s) } \\ \text { CT(s) } & \text { condensed tannin(s) } \\ \text { C } & \text { Carbon } \\ \text { SLA } & \text { specific leaf area }\end{array}$

\section{Introduction}

Boreal forests are nitrogen-limited (Tamm 1991; Vitousek and Howarth 1991), and thus the addition of 
$\mathrm{N}$ to these ecosystems can have great effects. Anthropogenic $\mathrm{N}$ enters boreal forests from two main sources. Firstly, forests receive $\mathrm{N}$ through atmospheric deposition derived from fossil fuel combustion, and from ammonia volatilization in agriculture (Galloway et al. 2008; Gundale et al. 2011). Additionally, to increase forest production, land managers in boreal regions (e.g. Scandinavia) increasingly apply fertilizers to forests (Lindkvist et al. 2011). These two types of anthropogenic $\mathrm{N}$ inputs can have numerous consequences in $\mathrm{N}$-limited boreal forests, such as increase net primary productivity and aboveground carbon (C) stocks (De Vries et al. 2006; Gundale et al. 2014), alter species composition and community structure (Bobbink et al. 1998 and references therein; Nordin et al. 1998; Strengbom et al. 2003; Nordin et al. 2006), and reduce diversity (Nordin et al. 2005; Bobbink et al. 2010; Meunier et al. 2016). While impacts of $\mathrm{N}$ enrichment on aboveground properties are well studied, relatively little is known about how soil processes respond to $\mathrm{N}$ enrichment (but see e.g. Janssens et al. 2010; Maaroufi et al. 2015), and in particular whether genetic variation within plant species modifies how soil processes respond to eutrophication (Sundqvist et al. 2012; Kumordzi et al. 2014).

Litter decomposition is a key soil process that is potentially influenced by $\mathrm{N}$ enrichment, and which is critical for nutrient recycling in boreal forests (Prescott 2010; Wardle et al. 2012). Studies that have looked at how decomposition is affected by N, however, have not yielded consistent results. In a meta-analysis, Knorr et al. (2005) found that the effect of $\mathrm{N}$ addition on decomposition can be positive, negative, or neutral depending on the initial quality of the litter, the fertilization rate, and the site-specific $\mathrm{N}$ deposition level. Litter quality and litter decomposition have been reported to vary both among species (Parsons et al. 2008; Janssens et al. 2010), and among individuals within species (LeRoy et al. 2007; Madritch et al. 2007a; Silfver et al. 2007). For example, Silfver et al. (2007), who studied decomposition for 19 silver birch (Betula pendula Roth) genotypes (GTs), observed that the highest genotypic mean for mass loss was $28 \%$ higher than the lowest genotypic mean after a three months incubation period. Key foliar traits known to influence litter quality, such as $\mathrm{C}: \mathrm{N}$ ratios or lignin concentrations, can vary significantly among GTs (LeRoy et al. 2007; Madritch et al. 2007a; LeRoy et al. 2012), and may help explain genotypic variation in decomposition rates.
Condensed tannins (CTs) are another aspect of plant litter chemistry known to vary substantially across different GTs. In a study with 31 GTs of the North American aspen, Populus tremuloides Michx., Lindroth and Hwang (1996) found that condensed tannin concentrations varied more than 2-fold between the GT expressing the lowest and the highest concentration, respectively. Also, for the related European aspen, Populus tremula L., a keystone species in the boreal region (Siitonen and Martikainen 1994; Kouki et al. 2004), substantial genotypic variations in tannin concentrations have been reported (Robinson et al. 2012; Bandau et al. 2015). Tannins have long been recognized for their potential role in defending plants against generalist herbivores and pathogens (Kraus et al. 2003; Holeski et al. 2009; Barbehenn and Constabel 2011; Robinson et al. 2012), but they are increasingly also acknowledged to influence soil processes, such as litter decomposition (Kraus et al. 2003; Madritch et al. 2006; Schweitzer et al. 2008; Madritch and Lindroth 2015), through their resistance to degradation by soil microbes, as well as their ability to bind and stabilize plant proteins or microbial enzymes (Benoit and Starkey 1968; Fierer et al. 2001; Kraus et al. 2003 and references therein; Joanisse et al. 2007).

While there is substantial literature demonstrating that $\mathrm{N}$ by itself can impact decomposition rates (Knorr et al. 2005, and references therein), far fewer studies have looked at how plant genetic variability modifies the impacts of $\mathrm{N}$ on leaf quality and thus litter decomposition (i.e. GT by $\mathrm{N}$ interactions). Of the very limited number of studies of this type (e.g. Madritch et al. 2006; LeRoy et al. 2012), no study has yet considered these potential GT by $\mathrm{N}$ interactions using $\mathrm{N}$ treatments relevant for understanding eutrophication in the boreal region (i.e. atmospheric $\mathrm{N}$ deposition or industrial forest fertilization). Thus, there remains a poor understanding of how anthropogenic $\mathrm{N}$ inputs impact soil processes including litter decomposition in boreal forests, and how these impacts may vary across the genetically diverse boreal forest landscape.

We conducted an experiment using European aspen to understand how $\mathrm{N}$ enrichment and genetic variability interacted to influence litter decomposition rates. Replicates of $10 \mathrm{GTs}$, that varied greatly in their baseline (i.e. constitutive) condensed tannin concentrations (5 lowand high-tannin GTs), were grown on a forest clear cut and subjected to three $\mathrm{N}$ addition rates, that represented anthropogenic $\mathrm{N}$ inputs into boreal forests. Green leaves 
and litter were collected for chemical analyses, and litter was used to conduct a decomposition assay in a controlled lab environment to understand which tissue properties best explained variation in decomposition rates across different GTs and $\mathrm{N}$ treatments. We addressed the following questions: First, we asked whether GT and constitutive tannin level (low or high tannin group (Tgr)) interacted with $\mathrm{N}$ addition to affect physical and chemical properties of leaves, and whether these leaf properties eventually impacted the quality of the litter that the plants produced. Based on predictions of several plant defense hypotheses (reviewed in Stamp 2003), we hypothesized that $\mathrm{N}$ addition will cause a decrease in the concentrations of products derived from the phenylpropanoid pathway (e.g. CTs, lignin), but that these responses would be individualistic for different GTs (see e.g. Donaldson et al. 2006; LeRoy et al. 2012; Bandau et al. 2015). Furthermore, we hypothesized that leaf and litter trait values will be correlated, as has been previously shown (King et al. 2001; Schweitzer et al. 2004). Secondly, we asked whether GTs and Tgrs interacted with $\mathrm{N}$ addition to influence litter decomposition rates. Based on results from a metaanalysis which found that $\mathrm{N}$ addition accelerated decomposition of litter from easily degradable tree genera, such as Populus (Janssens et al. 2010), we hypothesized that plant $\mathrm{N}$ enrichment will have a positive effect on decomposition rates in our experiment. Further, we hypothesized that plant $\mathrm{N}$ enrichment will enhance decomposition more for some GTs than for others, especially for plants with low constitutive tannin levels compared to ones with high tannin levels, because constitutive tannin production has the potential to have a negative effect that over-rides the hypothesized positive effect of $\mathrm{N}$ on decomposition. Answering these questions will provide us with new insights into how decomposition of litter from genetically diverse origins will respond to anthropogenic $\mathrm{N}$ enrichment.

\section{Material and methods}

Plant material and study area

We used ten European aspen (Populus tremula L.) GTs from the Swedish Aspen Collection (SwAsp), which comprises a total of 116 GTs from throughout Sweden that have been planted in two common gardens (Luquez et al. 2008). Based on previous data on foliar CT concentrations in the trees grown in the two gardens, we selected five GTs that consistently expressed low (GTs 18, 23, 50, 60, and 115) and five GTs with high (GTs 5, 26, 51, 65, and 72) levels of foliar CTs (see Fig. S1 in Bandau et al. 2015). A detailed description of the GT selection can be found in Bandau et al. (2015). Variation in latitude was equally represented among the selected low- and high-tannin GTs. The plants were propagated from the SwAsp in-vitro tissue culture kept at Umeå Plant Science Centre. In early May 2010, a surplus of plants per GT were potted, and then grown under optimal conditions in the greenhouse. After eight weeks, the plants were moved to a wind-sheltered, partly shaded out-door environment for acclimatization. In early August 2010, 30 even-sized, healthy clones of each GT (i.e. 300 individuals) were planted on a clear cut at the Swedish University of Agricultural Sciences (SLU) Kulbäcksliden experimental forest ( $\mathrm{N} \mathrm{64^{ \circ }} 9^{\prime}$ 8.02", E $19^{\circ} 35^{\prime} 12.09^{\prime \prime}$; WGS84 reference system) in a random block design. The experimental site was adjacent to a natural aspen stand, and was fenced in to exclude large herbivores. The plants were planted with a spacing of approximately two meters, and to avoid edge effects additional aspens were planted to surround the experimental plants.

Within each of the five blocks, plants were randomly assigned to one of three $\mathrm{N}$ treatments: 0,15 , or $150 \mathrm{~kg} \mathrm{~N} \mathrm{ha}^{-1} \mathrm{yr}^{-1}$, equivalent to ambient $\mathrm{N}$ conditions in the region (Gundale et al. 2014, and references therein), maximum $\mathrm{N}$ deposition rates currently observed in boreal forests (Gundale et al. 2011), and $\mathrm{N}$ fertilization rates typically used by today's forest industry, respectively. Nitrogen was applied as granulated $\mathrm{NH}_{4} \mathrm{NO}_{3}$ to the soil in a $25-\mathrm{cm}$-radius around each plant. Fertilization was carried out during three consecutive years beginning in 2011, with three applications per year (in May, June and July).

\section{Leaf sampling}

On 16 July 2013 (i.e. 26 months after the first $\mathrm{N}$ addition), we harvested leaves from each plant to assess leaf traits expressed during the growing season (hereafter referred to as leaf traits). Depending on the leaf size, we carefully cut $5-10$ of the most recently fully expanded leaves (about $1.5 \mathrm{~g}$ ) at the base of the petiole, placed them in a cooler, and brought them to the laboratory. We then measured leaf areas with a leaf area meter (LI3000C mounted on LI-3050C, Li-Cor®, Lincoln, NE, 
USA), after which leaves were freeze-dried to constant weight, and subsequently stored at $-20{ }^{\circ} \mathrm{C}$ until chemical leaf analyses were performed. We calculated specific leaf area (SLA) for each plant by dividing the total area of the leaves sampled per plant by their dry weight.

To obtain leaf litter from the same plants, we enclosed the crowns with mosquito netting before the onset of senescence. The nets were emptied on 8 October 2013 after most plants had lost their leaves, and no further resorption from the leaves was possible due to daily frost. Leaves not abscised by this time were manually removed and included in all analyses. In the laboratory, 10-20 leaves from each plant were randomly chosen for the assessment of chemical traits (hereafter referred to as litter traits). The selected leaves were freeze-dried, and stored at $-20{ }^{\circ} \mathrm{C}$. The remaining leaves were dried and used for a litter decomposition assay (see details below).

Chemical analyses of the leaf and litter samples

All freeze-dried green leaf and litter samples were coarse-ground on a Wiley ${ }^{\circledR}$ mill (mesh size \#10 (2 mm); Thomas Scientific, Swedesboro, NJ, USA) to obtain the required particle size for lignin and cellulose analysis (Bandau et al. 2015). Using a ball mill (Retsch® MM 400, Retsch®, Haan, Germany) a portion of each coarse-ground sample was further ground to a fine powder, which was used for analysis of CTs, C, and N. Due to a shortage of leaf and litter material, lignin and cellulose analysis were performed on pooled samples whereby equal amounts of either leaf or litter material were combined from all plant individuals within the same GT x N treatment combination, resulting in a total of 60 samples (i.e. 30 leaf and 30 litter samples). Qualitative tannin analysis was performed on 30 pooled litter samples only, because of the high cost and time requirement for this analysis. Quantitative analyses of C, N and CTs were performed on un-pooled samples.

Carbon and $\mathrm{N}$ content were assessed using dry combustion (LECO TruSpec CN Furnace, LECO Corporation, Lakeview, MI, USA), at the Department of Forest Ecology and Management, SLU Umeå. Lignin was measured with the acid-detergent fibre-sulphuric acid procedure (Helrich 1990), while cellulose was determined through nitric acid/acetic acid digestion, a subsequent reaction with anthrone, and measurement on a spectrophotometer at $620 \mathrm{~nm}$, as described in Updegraff (1969). Both lignin and cellulose analysis were performed at the Soil, Water and Plant Testing Laboratory at Colorado State University, USA. Soluble CTs were extracted with $70 \%$ acetone $+10 \mathrm{mM}$ ascorbic acid, and quantified using the acid-butanol method (Porter et al. 1986), and procyanidin $\mathrm{B} 2\left(\mathrm{C}_{30} \mathrm{H}_{26} \mathrm{O}_{12}\right.$; Sigma-Aldrich ${ }^{\circledR}$, St. Louis, MO, USA) as a standard. For further details see Bandau et al. (2015).

We used the phloroglucinol derivative method by Hagerman (2002a) for qualitative analyses of the tannin polymers. First, tannins were extracted from $200 \mathrm{mg}$ ground litter per sample with $70 \%$ acetone, and the acetone was subsequently removed using a vacuum evaporator. Ethanol was added to get the sample to $80 \%$ ethanol. After centrifuging (13,000 rpm for 3 mins), each tannin sample was purified from small molecular phenolics using Sephadex ${ }^{\text {TM }}$ LH-20 (Hagerman 2002b). Each purified tannin sample was then tested for two tannin precursors by HPLC (Randriamanana et al. 2014).

\section{Litter decomposition assay}

In mid Oct 2013, we initiated an incubation assay to determine the decomposability of litter from our plants, in agreement with previous precedures (e.g. Wardle et al. 2009; Sundqvist et al. 2011). To accomplish this, we first collected soil from a mixed-aged aspen forest near Sävar, Sweden (N 63 52' 59.68", E 20 33' 12.40") to provide a natural source of micro-organisms for decomposing aspen litter. Soil from the A-horizon (i.e. mineral soil) was brought to the laboratory, sieved (mesh size $1 \mathrm{~cm}$ ), and thoroughly mixed. Petri-dishes (15 cm diameter) were filled with $110 \mathrm{~g}$ of this soil (water content: $26 \%$ ). Any soil macro-fauna (e.g. snails and earthworms) were manually removed. A polyester mesh (mesh size $1 \mathrm{~mm}$ ) was placed on top of the soil, followed by leaf litter that had prior been dried at $30^{\circ} \mathrm{C}$ for 10 days. This low drying temperature was chosen to prevent volatilization of compounds that could potentially influence decomposition rates (Gundale et al. 2010), and to avoid the destruction of microbes growing on senescent leaves that may contribute to the decomposition process. Each petri-dish received approximately $0.75 \mathrm{~g}$ litter (actual mass was recorded) as whole leaves. We prepared two separate dishes for each source plant, however, in a few cases we only had enough litter for one. The two dishes per plant were considered subreplicates that were later averaged to generate a single mass loss value per plant. The dishes were sealed with Parafilm $M \circledR$ to avoid water loss, and incubated under 
standardized conditions that optimized decomposition (i.e. at $22{ }^{\circ} \mathrm{C}$ in darkness) for 353 days.

After incubation, the remaining litter was cleaned with deionized water, and oven-dried at $60{ }^{\circ} \mathrm{C}$ until reaching constant weight. Because initial and final litter were dried at different temperatures, a set of preincubation litter not included into petri-dishes was oven-dried at both $30{ }^{\circ} \mathrm{C}$ and $60{ }^{\circ} \mathrm{C}$. This allowed us to calculate the $60^{\circ} \mathrm{C}$ equivalent litter mass at the start of the incubation, which was then used to calculate the percent mass loss of litter in each dish after incubation $\left(\operatorname{mass} \operatorname{loss}(\%)=100-\frac{\text { final mass*100 }}{\text { initial mass }}\right)$. After incubation, we discovered a few petri-dishes (ca. $5 \%$ ) that had been contaminated by soil macro-fauna, which we discarded from all analysis.

\section{Statistical analysis}

To test the effect of N treatment, Tgr, and GT, and their interactions on leaf and litter traits, as well as on decomposition, we performed analyses of variance (ANOVAs) using a general linear model with a partially nested and crossed design. In these ANOVAs, $\mathrm{N}$ and Tgr served as main factors, and GT as a nested factor within Tgrs. We considered all three factors as fixed, including GT, because we deliberately chose specific $\mathrm{N}$ treatment levels, Tgrs, and GTs using a prior information. For the variables in which we had to pool samples with the same GT x N combination (i.e. lignin and cellulose content, lignin:cellulose and lignin: $\mathrm{N}$ ratio, catechin concentration, and chain length), we instead performed 2-way ANOVAs with $\mathrm{N}$ and Tgr serving as main factors. Prior to analysis, data were tested for assumptions of normality and homoscedasticity, and data were transformed as necessary. When a significant effect of the Tgr by $\mathrm{N}$ interaction was found, post hoc one-way ANOVAs and post hoc Gabriel's tests were performed to identify differences. We used Gabriel's test, because it is suitable for unbalanced designs/unequal sample sizes (Field 2009), such as were present for our data due to some mortality among our experimental plants.

To test whether leaf and litter traits were correlated to each other, we used non-parametric Spearman's correlation tests, because some of our variables had outliers and were not normally distributed, and hence did not fulfill the criteria for a parametric correlation test (i.e. Pearson's correlation test). We also used Spearman's correlation to investigate whether any of the measured litter traits could explain the significant GT, and the GT $x$ N effect, that were identified through our ANOVA for mass loss. For the main GT effect, these correlations were performed for average trait values for each GT (regardless of $\mathrm{N}$ level), and for the GT x N effect, the correlations were performed using average trait values for each GT for each N level.

All statistical analyses were performed using IBM ${ }^{\circledR}$ SPSS ${ }^{\circledR}$ statistics, version 21 (Armonk, NY, USA). We considered results with $P$-values below 0.05 as significant.

\section{Results}

Interactive effects of $\mathrm{N}$ with genotype and tannin group on leaf and litter traits

Interactive effects of GT and N were only found for one leaf trait, namely for CT concentrations (Table 1). This interaction was due to different combinations of GTs expressing low and high values under the different $\mathrm{N}$ levels (Fig. 1). Under ambient $\mathrm{N}$ conditions, CT levels were lowest in GTs 23 and 60, and highest in GT 65 (Fig. 1a), whereas at the low N treatment, GT 23 contained least CTs and GT 72 most, and at the high N level, GTs 18 and 60 had least CTs, and GTs 65 and 72 most. GT x N effects were also found for three out of four tested litter traits (i.e. $\mathrm{CTs}, \mathrm{N}$, and the $\mathrm{C}: \mathrm{N}$ ratio) (Table 1). The sources of these interactions are displayed in Fig. 1b-d.

Our ANOVAs further suggested interactive effects of Tgr and $\mathrm{N}$ for two traits, namely for CT concentrations in leaves and litter (Table 1). The post hoc one-way ANOVAs confirmed those effects, however, Gabriel's post hoc test could not clearly identify the source of the interaction for either the leaves or the litter (Fig. 2).

Main effect of $\mathrm{N}$ and genotype on leaf and litter traits

Five of nine leaf traits were affected by $\mathrm{N}$ addition, including leaf $\mathrm{CT}, \mathrm{C}$, and $\mathrm{N}$ content, the $\mathrm{C}: \mathrm{N}$ ratio, and SLA (Table 1). Means and standard errors for these traits for each of the three $\mathrm{N}$ levels are reported in Table S1. Foliar CTs, C and $\mathrm{N}$ content responded positively to $\mathrm{N}$ addition on average, whereas the $\mathrm{C}: \mathrm{N}$ ratio and SLA decreased on average when $\mathrm{N}$ was added.

The litter traits that were influenced by $\mathrm{N}$ addition were similar to the leaf traits affected by $\mathrm{N}$ treatment, with the exception of SLA, which was only measured on green leaves (Table 1). Responses of litter CTs, C, N, 
Table 1 ANOVA summary testing leaf and litter traits of Populus tremula and decomposition in response to nitrogen addition $(\mathrm{N})$, tannin group (Tgr), genotype nested within tannin group (GT(Tgr)), and interactions thereof. F-values (F) and denominator degrees of freedom (dfs) are followed by significance levels $(\mathrm{P})$.
Numerator degrees of freedom are displayed behind the individual factors in the top row. For variables for which only pooled data were available (e.g. lignin content), the results of 2-way ANOVAs that tested single and interactive effects of $\mathrm{N}$ and Tgr are shown

\begin{tabular}{|c|c|c|c|c|c|c|c|c|c|c|}
\hline \multirow[t]{2}{*}{ variables } & \multicolumn{2}{|l|}{$\mathrm{N}_{(2)}$} & \multicolumn{2}{|l|}{$\mathrm{GT}(\mathrm{Tgr})_{(8)}$} & \multicolumn{2}{|l|}{$\operatorname{Tgr}_{(1)}$} & \multicolumn{2}{|c|}{$\operatorname{GT}(\mathrm{Tgr}) \cdot \mathrm{N}_{(16)}$} & \multicolumn{2}{|l|}{$\operatorname{Tgr} \cdot \mathrm{N}_{(2)}$} \\
\hline & $\mathrm{F}_{(\mathrm{dfs})}$ & $\mathrm{P}$ & $\mathrm{F}_{(\mathrm{dfs})}$ & $\mathrm{P}$ & $\mathrm{F}_{(\mathrm{dfs})}$ & $\mathrm{P}$ & $\mathrm{F}_{(\mathrm{dfs})}$ & $\mathrm{P}$ & $\mathrm{F}_{(\mathrm{dfs})}$ & $\mathrm{P}$ \\
\hline \multicolumn{11}{|l|}{ leaf traits } \\
\hline $\begin{array}{l}\text { condensed tannins } \\
\left(\mathrm{mg} \mathrm{g}^{-1} \mathrm{DW}\right)\end{array}$ & 23.12 (226) & $<0.001$ & 23.45 (226) & $<0.001$ & $165.48(226)$ & $<0.001$ & 2.67 & 0.001 & $5.68(226)$ & 0.004 \\
\hline $\mathrm{C}$ content $(\%)$ & $33.21_{(227)}$ & $<0.001$ & $3.54_{(227)}$ & 0.001 & $0.98_{(227)}$ & 0.323 & $1.13_{(227)}$ & 0.326 & 0.05 (227) & 0.955 \\
\hline $\mathrm{N}$ content $(\%)$ & $99.79_{(227)}$ & $<0.001$ & $2.80_{(227)}$ & 0.006 & $19.50_{(227)}$ & $<0.001$ & $1.15_{(227)}$ & 0.313 & 0.56 & 0.571 \\
\hline $\mathrm{C}: \mathrm{N}$ ratio & $75.40_{(227)}$ & $<0.001$ & $4.17_{(227)}$ & $<0.001$ & $21.41_{(227)}$ & $<0.001$ & 1.42 (227) & 0.134 & $0.49_{(227)}$ & 0.611 \\
\hline SLA $\left(\mathrm{cm}^{2} \mathrm{~g}^{-1}\right)$ & $44.58_{(228)}$ & $<0.001$ & 7.22 (228) & $<0.001$ & $30.40_{(228)}$ & $<0.001$ & $1.45_{(228)}$ & 0.121 & $0.15_{(228)}$ & 0.863 \\
\hline lignin content (\%) & $0.05_{(24)}$ & 0.953 & $\mathrm{~N} / \mathrm{A}$ & N/A & $0.61_{(24)}$ & 0.444 & N/A & $\mathrm{N} / \mathrm{A}$ & 0.25 & 0.779 \\
\hline cellulose content $(\%)$ & $0.56(24)$ & 0.581 & N/A & N/A & $2.13_{(24)}$ & 0.158 & N/A & $\mathrm{N} / \mathrm{A}$ & 0.91 & 0.417 \\
\hline lignin:cellulose ratio & $0.32(24)$ & 0.733 & N/A & N/A & $1.30_{(24)}$ & 0.266 & N/A & $\mathrm{N} / \mathrm{A}$ & $0.84_{(24)}$ & 0.442 \\
\hline lignin: $\mathrm{N}$ ratio & $0.20_{(24)}$ & 0.822 & N/A & N/A & $0.31_{(24)}$ & 0.586 & N/A & N/A & $0.30_{(24)}$ & 0.747 \\
\hline \multicolumn{11}{|l|}{ litter traits } \\
\hline $\begin{array}{l}\text { condensed tannins } \\
\left(\mathrm{mg} \mathrm{g}^{-1} \mathrm{DW}\right)\end{array}$ & 6.95 (226) & 0.001 & 15.03 & $<0.001$ & 191.75 (226) & $<0.001$ & 2.94 & $<0.001$ & 4.91 (226) & 0.008 \\
\hline $\begin{array}{l}\text { catechin }\left(\mathrm{mg} \mathrm{g}^{-1}\right. \\
\text { purified CTs) }\end{array}$ & $0.64_{(24)}$ & 0.536 & N/A & N/A & 0.22 & 0.646 & N/A & $\mathrm{N} / \mathrm{A}$ & 0.01 & 0.991 \\
\hline chain length (catechin units) & $0.25(24)$ & 0.778 & $\mathrm{~N} / \mathrm{A}$ & N/A & $5.71_{(24)}$ & 0.025 & $\mathrm{~N} / \mathrm{A}$ & N/A & 0.53 & 0.595 \\
\hline $\mathrm{C}$ content $(\%)$ & $34.58_{(226)}$ & $<0.001$ & $1.36_{(226)}$ & 0.214 & $1.98_{(226)}$ & 0.161 & $0.88_{(226)}$ & 0.590 & $0.48_{(226)}$ & 0.617 \\
\hline $\mathrm{N}$ content $(\%)$ & 23.29 (226) & $<0.001$ & $4.48_{(226)}$ & $<0.001$ & $17.65(226)$ & $<0.001$ & $2.10_{(226)}$ & 0.009 & 0.93 (226) & 0.397 \\
\hline $\mathrm{C}: \mathrm{N}$ ratio & 20.82 (226) & $<0.001$ & $4.58_{(226)}$ & $<0.001$ & $17.10_{(226)}$ & $<0.000$ & $2.32_{(226)}$ & 0.004 & $0.07(226)$ & 0.932 \\
\hline lignin content $(\%)$ & $0.71_{(24)}$ & 0.500 & $\mathrm{~N} / \mathrm{A}$ & N/A & $2.05(24)$ & 0.165 & N/A & $\mathrm{N} / \mathrm{A}$ & $0.15_{(24)}$ & 0.861 \\
\hline cellulose content (\%) & 1.42 (24) & 0.261 & N/A & N/A & 3.51 (24) & 0.073 & N/A & $\mathrm{N} / \mathrm{A}$ & 0.01 & 0.991 \\
\hline lignin:cellulose ratio & $0.18_{(24)}$ & 0.835 & N/A & N/A & 0.23 & 0.633 & N/A & $\mathrm{N} / \mathrm{A}$ & 0.43 & 0.655 \\
\hline lignin: $\mathrm{N}$ ratio & $0.71_{(24)}$ & 0.503 & N/A & N/A & $0.01(24)$ & 0.907 & N/A & $\mathrm{N} / \mathrm{A}$ & 0.31 & 0.734 \\
\hline \multicolumn{11}{|l|}{ decomposition } \\
\hline mass loss $(\%)$ & $3.40_{(212)}$ & 0.035 & $7.05_{(212)}$ & $<0.001$ & $3.00_{(212)}$ & 0.085 & $1.86_{(212)}$ & 0.025 & $0.25_{(212)}$ & 0.781 \\
\hline
\end{tabular}

and $\mathrm{C}: \mathrm{N}$ ratio were identical to those observed for the leaves (Table $\mathrm{S} 1$ ).

Main effects of GT were found for many leaf traits, including CTs, $\mathrm{C}$ and $\mathrm{N}$, the $\mathrm{C}: \mathrm{N}$ ratio, and SLA, as well as for three litter traits, namely $\mathrm{CTs}, \mathrm{N}$ and the $\mathrm{C}: \mathrm{N}$ ratio (Table 1). Table S2 provides further information about which GTs consistently expressed low and high values for the individual traits, regardless of the $\mathrm{N}$ treatment level they were subjected to.

Main effect of tannin group on leaf and litter traits

Main effects of Tgr were found for four of nine leaf traits (CTs, $\mathrm{N}$, the $\mathrm{C}: \mathrm{N}$ ratio, and SLA) (Table 1). Plants in the low Tgr showed lower foliar CT concentrations than plants in the high Tgr (Fig. 3a). Leaves of low-tannin plants also had a lower $\mathrm{C}: \mathrm{N}$ ratio than leaves of hightannin plants (Fig. 3c). Contrary, plants in the low Tgr had a higher leaf $\mathrm{N}$ content (Fig. $3 \mathrm{~b}$ ) and a greater SLA (Fig. 3d) than plants in the high Tgr.

We also detected main Tgr effects for four out of ten litter traits, specifically for CTs, the chain length of the catechin units, $\mathrm{N}$ content, and the $\mathrm{C}: \mathrm{N}$ ratio (Table 1). Litter of plants in the low Tgr contained less CTs than litter of those in the high Tgr (Fig. 3e). Low-tannin plants further possessed shorter catechin chains (Fig. 3h), had a lower C:N ratio (Fig. 3g) and higher $\mathrm{N}$ content in litter (Fig. 3f) compared to high-tannin plants. 
Fig. 1 Reaction norm plots showing leaf and litter traits for which the ANOVAs (Table 1) indicated significant interative effects of GT(Tgr) and N. Displayed are mean condensed tannin concentrations in leaves (a) and litter (b), nitrogen content in litter (c), and the C:N ratio of litter (d). Hollow symbols represent plants with an intrinsically low, and filled symbols plants with an intrinsically high tannin production a

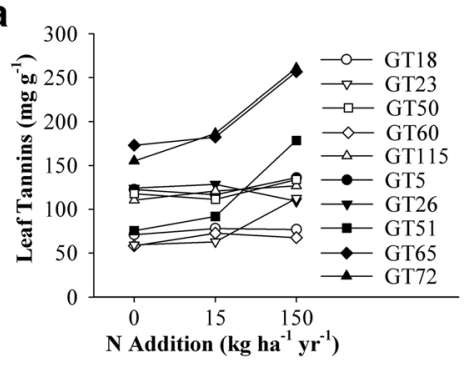

b

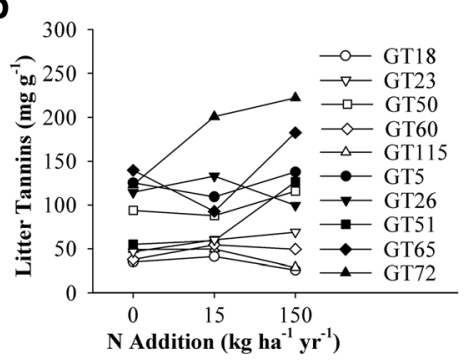

C

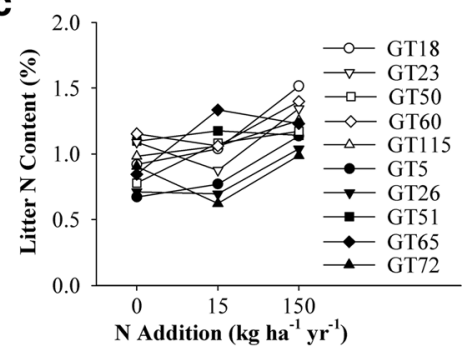

d

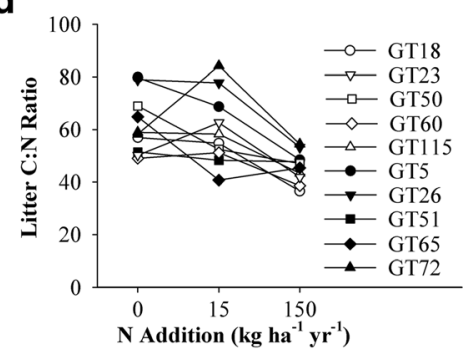

Correlation between leaf and litter traits

We found that leaf and litter values were strongly positively correlated with each other for four of the eight traits that were assessed on both leaves and litter (i.e. for $\mathrm{CT}$ concentrations, $\mathrm{C}$ and $\mathrm{N}$ content, and the $\mathrm{C}: \mathrm{N}$ ratio) (Fig. 4a-d). For the other four traits, correlations between leaf and litter values were weaker or totally absent (Fig. 4e-h).

Effects of nitrogen, genotype and tannin group on litter decomposition

Variation in mass loss could be explained by significant interactive and main effects of GT and N treatment, as well as by a marginally significant main effect of Tgr (Table 1, Fig. 5). The interactive effect of GT and N occurred, because under ambient $\mathrm{N}$ conditions mass loss did not differ between GTs, whereas under the low N treatment litter from GT 65 decomposed slowest and from GTs 23, 50, 60, 5, 26 and 51 fastest, and under the high $\mathrm{N}$ level litter from GT 115 decomposed slowest, and litter from GTs 23, 26 and 60 decomposed fastest (Fig. 5). Mean mass loss and standard error values for each $\mathrm{N}$ treatment level, and each GT are reported in Table S1 and $\mathrm{S} 2$, respectively. Mass loss decreased in response to $\mathrm{N}$ addition, when data were averaged across all ten GTs (Table S1). The marginally significant main effect of Tgr occurred because low-tannin plants decomposed slightly faster than high-tannin plants (low Tgr: $55.98 \pm 0.55 \%$, high Tgr: $55.39 \pm 0.45 \%)$.

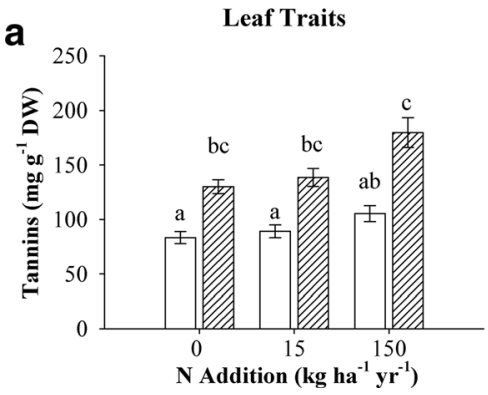

Fig. 2 Leaf and litter traits for which the ANOVAs (Table 1) indicated significant interactive effects of tannin group (Tgr) and $\mathrm{N}$ treatment. Displayed are mean $( \pm \mathrm{SE})$ condensed tannin concentrations in leaves (a) and litter (b). White bars represent plants with

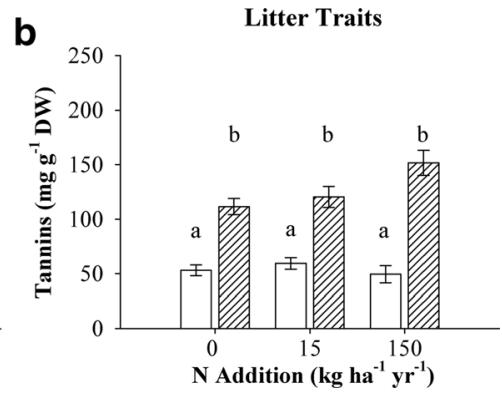

an intrinsically low, and hatched bars plants with an intrinsically high tannin production. Post hoc letters derived from Gabriel's tests are displayed above the bars. Different letters indicate significant differences in means 
Fig. 3 Leaf and litter traits for which the ANOVAs (Table 1) indicated significant main effects of tannin group (Tgr). Displayed are mean $( \pm \mathrm{SE})$ condensed tannin concentrations in leaves (a) and litter (e), nitrogen content in leaves (b) and litter (f), C:N ratios of leaves (c) and litter (g), SLA of leaves (d), and the chain length of tannin molecules in litter (h). White bars represent plants with an intrinsically low, and hatched bars plants with an intrinsically high tannin production

Leaf Traits

a

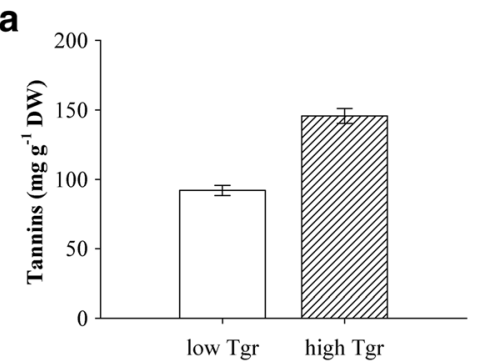

b

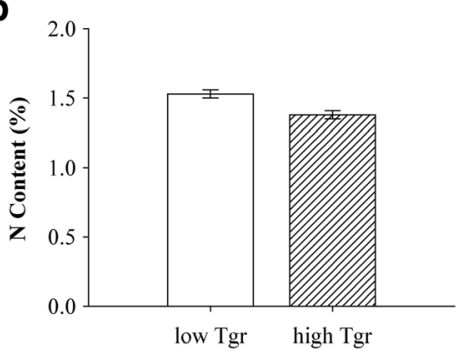

C

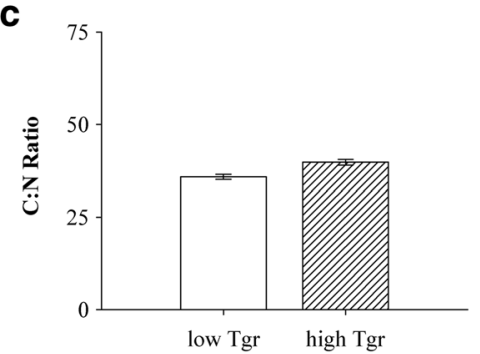

d

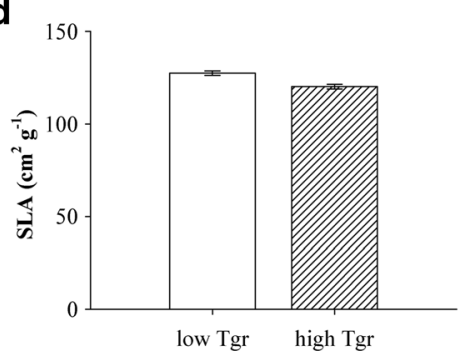

Litter Traits

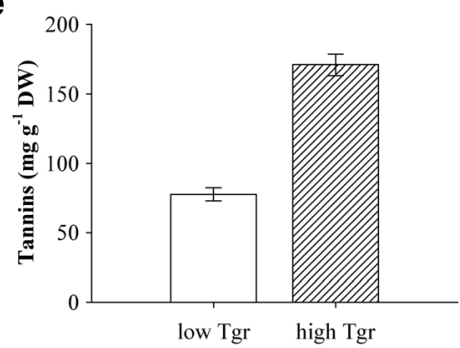

f

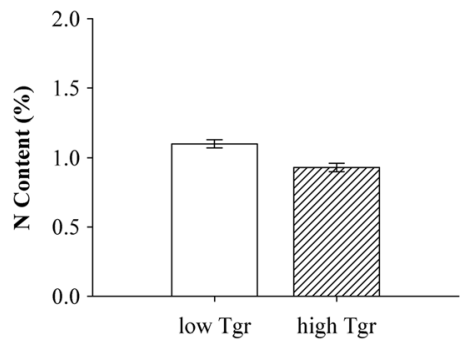

g

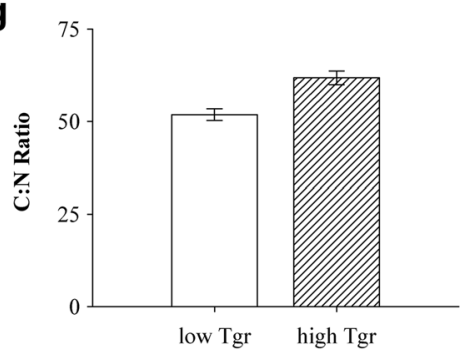

h

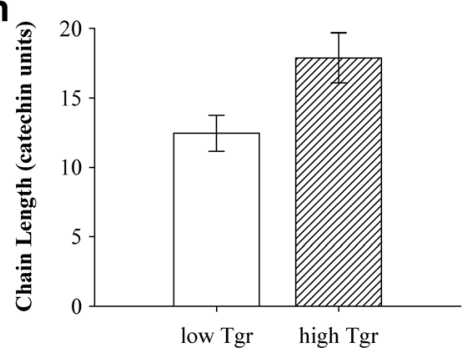

Correlation between traits and mass loss

When data were averaged for each GT across all three $\mathrm{N}$ treatment levels (Table S3), SLA was positively correlated with mass loss (Fig. 6 a), whereas the lignin:N ratio negatively affected mass loss (Figs. 6 b).

When traits were correlated with mass loss within each $\mathrm{N}$ addition level, SLA and three of the ten litter traits (catechin concentrations, cellulose content, and the lignin: $\mathrm{N}$ ratio) were correlated with mass loss within at least one $\mathrm{N}$ treatment level (Table S4). For SLA, positive correlations were present at the low and the high $\mathrm{N}$ treatment (Fig. 7a). Catechin concentrations were positively correlated with mass loss under ambient $\mathrm{N}$ conditions (Fig. 7b). Cellulose content was negatively correlated with mass loss under ambient $\mathrm{N}$ conditions (Fig. 7c), and the lignin: $\mathrm{N}$ ratio was negatively correlated with mass loss both under ambient and high $\mathrm{N}$ conditions (Fig. 7d).

\section{Discussion}

We sought to understand how N, genotype, and constitutive tannin levels interacted to affect leaf traits of P. tremula L. Contrary to our hypothesis, we rarely 
Fig. 4 Relationship between leaf and litter values for chemical traits, including: a condensed tannin concentrations, $\mathbf{b}$ carbon content, $\mathbf{c}$ nitrogen content, $\mathbf{d} \mathrm{C}: \mathrm{N}$ ratio, e lignin content, $\mathbf{f}$ cellulose content, $\mathbf{g}$ lignin:cellulose ratio, and $\mathbf{h}$ lignin: $\mathrm{N}$ ratio. Within each panel Spearman's correlation coefficient $\left(\mathrm{r}_{\mathrm{s}}\right)$, the $P$-value $(\mathrm{P})$ and the samples size (n) are given. For significant correlations $(P<0.05), \mathrm{r}_{\mathrm{s}}$ and $P$-values are marked in bold a

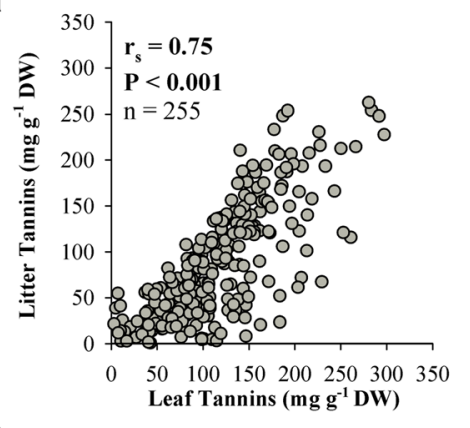

c

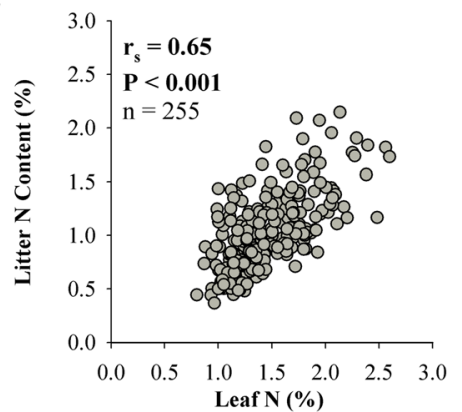

e

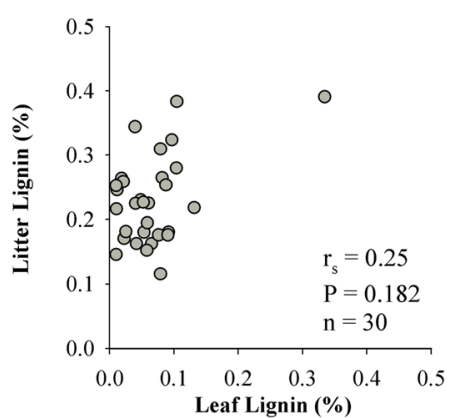

g

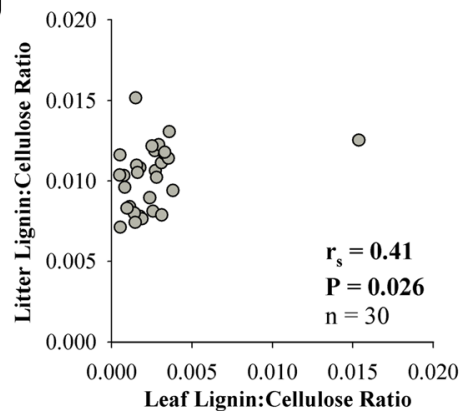

b

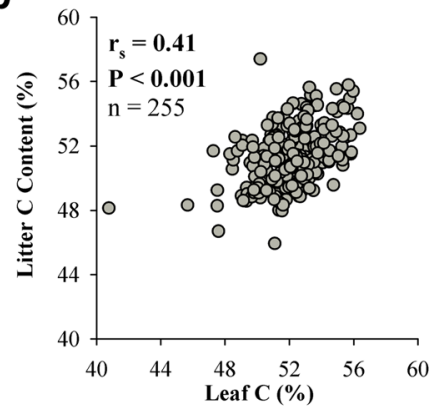

d

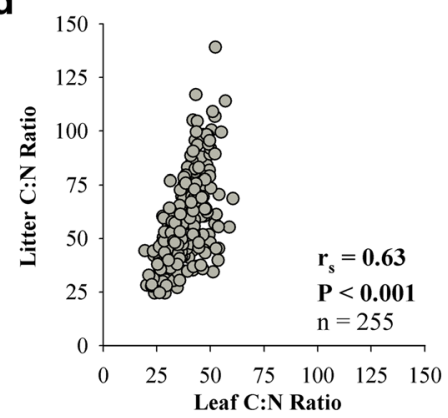

f

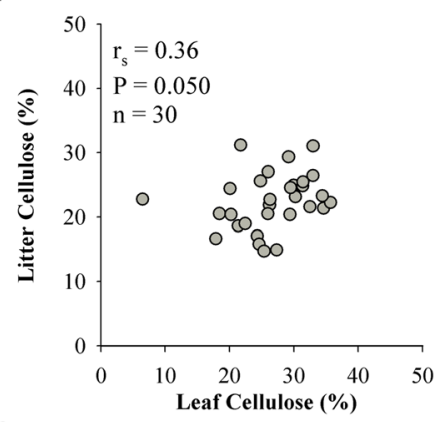

h

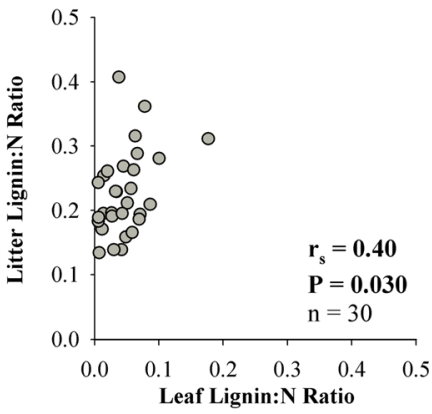

observed interactive effects of $\mathrm{N}$ and GT, and of $\mathrm{N}$ and Tgr on leaf traits. The only leaf trait for which we found these interactions, were foliar CTs. For leaf CTs, these interactions occurred because high-tannin GTs tended to be more responsive to $\mathrm{N}$ addition than low-tannin GTs. In contrast to the few interactive effects, our data showed strong main effects of $\mathrm{N}$ and GT, as well as Tgr effects on leaf traits. Nitrogen addition by itself caused an increase in both leaf $\mathrm{N}$ and $\mathrm{C}$ content, and a decrease in the $\mathrm{C}: \mathrm{N}$ ratio, consistent with other studies (Hemming and Lindroth 1999; Glynn et al. 2003; Madritch et al. 2007a; Bandau et al. 2015). Similar to a study that exposed the same GTs to the same N levels for one season (Bandau et al. 2015), we found that leaf lignin was unresponsive to $\mathrm{N}$. We further observed that foliar $\mathrm{CT}, \mathrm{C}$ and $\mathrm{N}$ content, the $\mathrm{C}: \mathrm{N}$ ratio, and SLA 


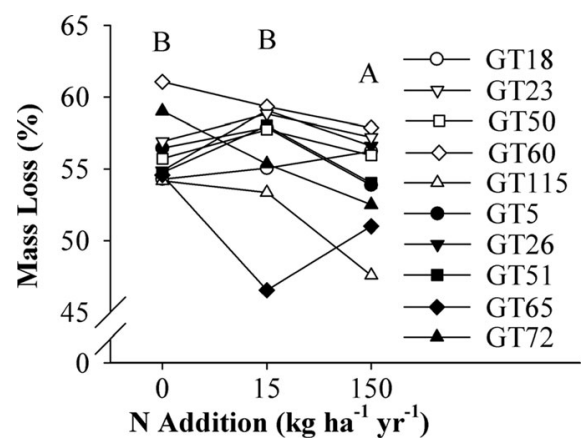

Fig. 5 Reaction norm plot showing mass loss for litter of ten aspen genotypes, that were grown under three $\mathrm{N}$ treatments, after an incubation at $22{ }^{\circ} \mathrm{C}$ for 353 days. Hollow symbols represent plants with an intrinsically low, and filled symbols plants with an intrinsically high tannin production. Post hoc letters derived from Gabriel's test that tested the $\mathrm{N}$ treatment effect are displayed. Different letters indicate significant differences in means

varied substantially among GTs, which is in agreement with other studies on Populus (Lindroth and Hwang 1996; Madritch et al. 2007a; Madritch et al. 2014; Randriamanana et al. 2014; Bandau et al. 2015). Constitutive tannin level (i.e. Tgr) also affected a number of leaf traits besides tannin concentrations. Consistent with previous research (Harding et al. 2009), low-tannin plants showed higher leaf growth, and thus a larger SLA, a higher leaf $\mathrm{N}$ content, and lower foliar $\mathrm{C}: \mathrm{N}$ ratios than high-tannin plants.

Contrary to our previous study (Bandau et al. 2015), and predictions of some plant defense hypotheses (reviewed in Stamp 2003), we found that foliar CTs in this current study responded positively to $\mathrm{N}$ addition. There are several potential explanations for the different impact of $\mathrm{N}$ on tannins that we found in our current experiment. One reason could be that fertilized plants experienced more damage by antagonists (e.g. by leafchewing insects, and by Venturia shoot blight; personal
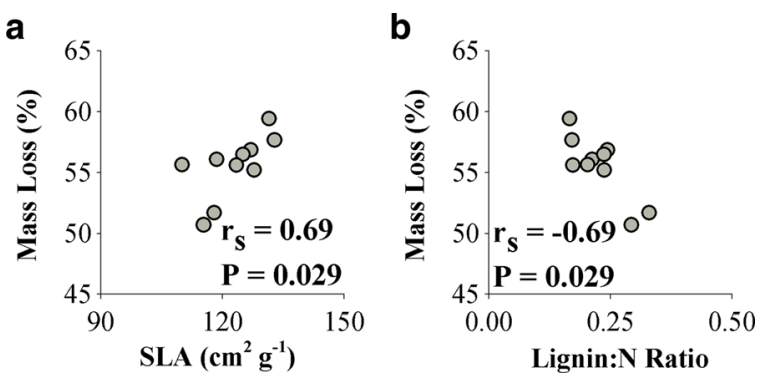

Fig. 6 Relationships between SLA (a), lignin:N ratio (b) and mass loss averaged for each genotype across all $\mathrm{N}$ treatments. Spearman's correlation coefficient $\left(\mathrm{r}_{\mathrm{s}}\right)$, and the $P$-value $(\mathrm{P})$ are given. For significant correlations $(P<0.05), \mathrm{r}_{\mathrm{s}^{-}}$and $P$-values are marked in bold observation), which in turn could have induced tannin production. Antagonists may have been more attracted to fertilized plants because of their higher leaf $\mathrm{N}$ content and relatively low initial tannin concentrations (Bandau et al. 2015). Osier and Lindroth (2006), for example, found that gypsy moth (Lymantria dispar L.) larvae grew faster and larger on fertilized aspens than on nonfertilized ones. Several studies have also shown that damage can induce condensed tannin production (Stevens and Lindroth 2005; Barbehenn and Constabel 2011 and references therein). Hence, the initial attraction of antagonists to the better conditions provided by fertilized plants, and subsequent defense induction, could explain the elevated tannin concentrations in fertilized plants in our current study. The growth differentiation balance hypothesis (GDBH) (Herms and Mattson 1992) may provide an additional explanation for the increase in tannins that we observed with $\mathrm{N}$ addition, because it predicts a parabolic relationship between secondary metabolite production and resource availability. For low nutrient supply, the GDBH proposes that carbohydrates are to a greater extent allocated to the synthesis of secondary metabolites relative to growth. Thus, the positive relationship between $\mathrm{N}$ addition and tannins could have occurred because all plants within our field study grew under resource limitated conditions, and hence were confined to a soil nutrient gradient that covered only the ascending phase of the parabolic curve.

In addition to the differences in leaf traits that occurred in response to N, and among GTs and Tgrs, we also found that leaf and litter values were positively correlated for a number of traits, which agrees with previous studies (King et al. 2001; Schweitzer et al. 2004). The correlations between leaf and litter values, and the results of the ANOVAs demonstrate that many of the factors that affected some leaf chemistry traits also had significant effects on many of the same litter chemistry traits (i.e. main effects of N, GT, and Tgr). These results suggest that the genetic and environmental factors that influcened litter traits may also have an effect on decomposition, which would agree with the suggestion of Schweitzer et al. (2004) that genetically based variation in plant traits may not only be important for a plant population itself, but may result in important extended phenotypes that could alter ecosystem functioning.

The extended phenotype concept (Schweitzer et al. 2004) was more explicitly addressed in our second question. We predicted that $\mathrm{N}$ addition would increase 


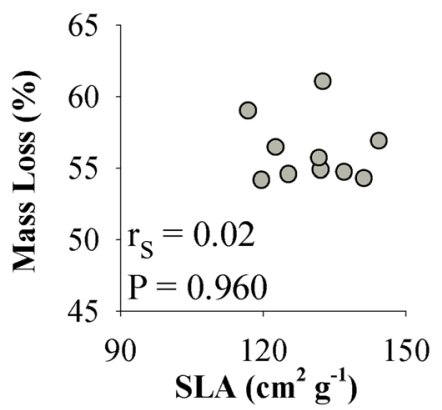

b

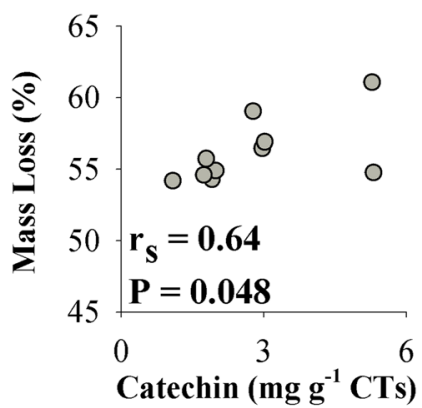

C
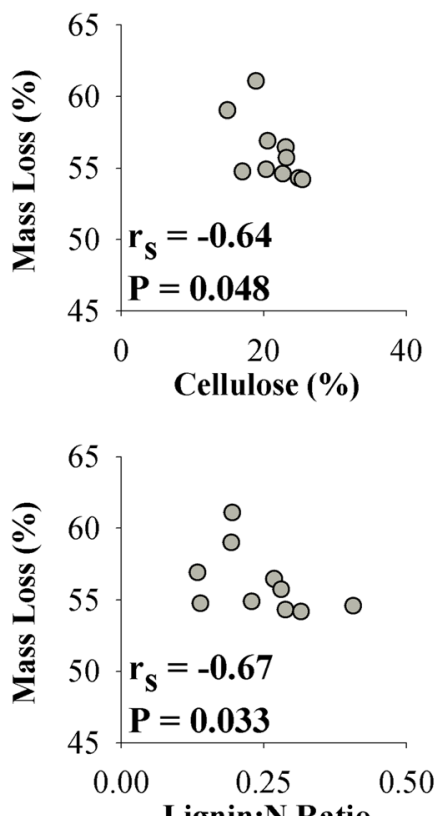

Lignin:N Ratio
N Addition

$15 \mathrm{~kg} \mathrm{ha}^{-1} \mathrm{yr}^{-1}$
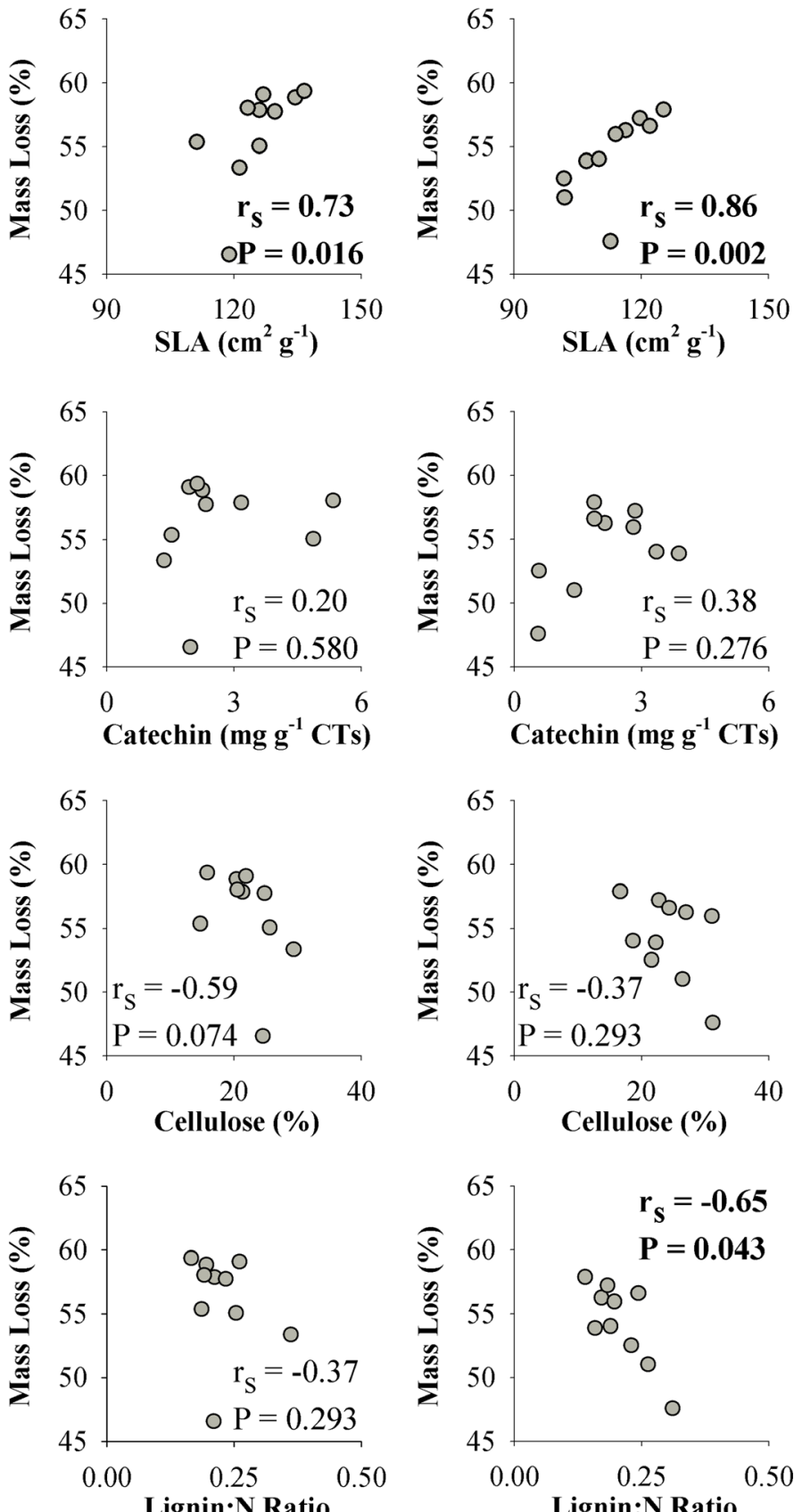

Fig. 7 Relationships between SLA, litter traits and mass loss averaged for each genotype within each $\mathrm{N}$ treatment. Traits displayed are: SLA (a), catechin concentration (b), cellulose

decomposition rates through an improvement of litter quality, but with variation among GTs and between content (c), and lignin:N ratio (d). Spearman's correlation coefficient ( $\left.\mathrm{r}_{\mathrm{s}}\right)$, and the $P$-value (P) are given. For significant correlations $(P<0.05), \mathrm{r}_{\mathrm{s}}$ - and $P$-values are marked in bold

Tgrs. In partial agreement with our prediction, we found that mass loss was influenced by main effects of $\mathrm{N}$ and 
GT, and a marginally significant main effect of Tgr. The Tgr effect was caused by low-tannin plants decomposing slightly faster than high-tannin plants. This agrees with the hypothesized negative effect of tannins on decomposition (Kraus et al. 2003), and with observations of several other studies, which showed that tannins decreased decomposition rates (Driebe and Whitham 2000; Madritch et al. 2006; LeRoy et al. 2007; Liu et al. 2009). The main effect of $\mathrm{N}$ was due to reduced mass loss in response to the high $\mathrm{N}$ treatment. This observation is inconsistent with our prediction and contrasts many other studies that described increases in decomposition rates of Populus litter with added N (e.g. Madritch et al. 2006; Janssens et al. 2010; Nikula et al. 2010). However, our finding is supported by at least one other Populus study (LeRoy et al. 2012). The unexpected reduction in SLA in response to the high $\mathrm{N}$ level could provide an explanation for why $\mathrm{N}$ addition caused a reduction in mass loss in our study. SLA is well known to be positively correlated with mass loss (Cornwell et al. 2008; Garnier and Navas 2012), and contrary to our study usually increases in response to $\mathrm{N}$ addition (Knops and Reinhart 2000). The reduction in SLA in response to added $\mathrm{N}$ in our study could have been a result of leaf mass increasing more rapidly in response to $\mathrm{N}$ than leaf area. This could have occurred because low resource availability at our site may have limited plant growth (i.e. the increase in leaf area), but promoted secondary metabolite production (i.e. the increase in leaf mass), as predicted by the GDBH (Herms and Mattson 1992).

The significant effect of GT on decomposition shown in our study agrees with studies focused on other deciduous broad leaved trees, including Populus tremuloides Michx. (Madritch et al. 2006; LeRoy et al. 2012), Populus angustifolia James (LeRoy et al. 2007), Betula pendula Roth (Silfver et al. 2007; Silfver et al. 2015), and Quercus laevis Walter (Madritch and Hunter 2002, 2005). Our correlation analysis between average litter traits for each GT (i.e. averaged across all three N levels) and mass loss (Table S3, Fig. 6) provides some further insight into understanding why litter decomposition varied among the GTs. Two specific traits, i.e. SLA and the lignin: $\mathrm{N}$ ratio, were correlated with mass loss, and thus likely explain the GT effect we observed. SLA and mass loss were positively correlated, which agrees with other studies focused on intra-specific variation (e.g. Sundqvist et al. 2011; Jackson et al. 2013), whereas the lignin: $N$ ratio was negatively correlated with mass loss, consistent with substantial literature indicating the importance of lignin as a control of decomposition rates (e.g. Zhang et al. 2008; Talbot et al. 2012 and references therein).

Regarding interactive effects, we found no evidence that constitutive tannin levels altered the effect of $\mathrm{N}$ on decomposition. We did, however, find significant interactive effects of $\mathrm{N}$ addition and GT, indicating that litter decomposition of some GTs were significantly more responsive to $\mathrm{N}$ addition than others. This finding is consistent with some previous studies on $P$. tremuloides Michx. (Madritch et al. 2006; LeRoy et al. 2012), but to the best of our knowledge our study represents the first that looked at these interactions in P. tremula L. using N addition levels relevant for understanding eutrophication in the boreal region. Our correlation analyses between average litter traits and mass loss for each GT within the individual $\mathrm{N}$ treatment levels (Table S4, Fig. 7) provided further insights into these interactions. Specifically, we found that many of the traits that varied substantially among the GTs correlated with mass loss under some N addition levels more than others, suggesting a shift in the importance of specific traits in controlling decomposition across the different $\mathrm{N}$ levels. For instance, we found no correlation between SLA and mass loss under ambient $\mathrm{N}$ conditions, but positive correlations within both the low and high $\mathrm{N}$ treatment (Fig. 7a). The increased importance of SLA could suggest that leaf structural properties versus chemical properties become relatively more important in controlling decomposition in $\mathrm{N}$ enriched environments. Consistent with this, several chemical traits appeared to be relatively more important in controlling decomposition under ambient $\mathrm{N}$ conditions (e.g. catechin and cellulose concentrations). The negative relationship between cellulose and mass loss under ambient conditions was somewhat surprising given that cellulose is considered a relatively labile substrate (Madritch et al. 2007b; Chomel et al. 2015). However, cellulose does not contain any $\mathrm{N}$ and its mineralization can be limited when microbes lack sufficient $\mathrm{N}$ to balance their stoichiometry (Stark et al. 2014), thus potentially explaining this result. Our findings highlight that many traits vary substantially among GTs, and these traits can have varying influences on decomposition, depending on how much $\mathrm{N}$ a plant is able to acquire from its environment.

\section{Conclusions}

Using P. tremula GTs obtained from a broad geographical range of Sweden, our data provide important 
insights regarding the influence of $\mathrm{N}$ enrichment and plant genetic variability on litter decomposition in boreal forests. First, our work shows that as a plant acquires more $\mathrm{N}$, its litter will not necessarily decompose faster, as suggested by several previous studies. Instead our study suggests that $\mathrm{N}$ enrichment can also sometimes decelerate litter decomposition, which may occur as a result of corresponding morphological (i.e. SLA) changes to litter. Secondly, our data show that decomposition rates can strongly vary across genetically different individuals, due to heritable differences in their SLA and lignin: $\mathrm{N}$ ratios, and to a lesser extent in their soluble foliar tannin concentrations. Thirdly, our work shows that genetic variability within a tree species can strongly modify how a key environmental change factor (i.e. $\mathrm{N}$ enrichment) modifies plant litter decomposition. Specifically, our data suggest that $\mathrm{N}$ enrichment causes a shift in which traits most strongly influence decomposition, and because different individuals exhibit heritable differences in these traits, litter decomposition is much more responsive to $\mathrm{N}$ enrichment for some GTs than others. These findings highlight that the considerable genetic diversity present in tree species can have a strong influence on ecosystem processes such as decomposition, and thus influence how these processes respond to environmental change.

Acknowledgments We thank Sara Christiansson and Lena Jonsson for their help when establishing the experiment. Furthermore, we are grateful to Hayden Elza and Sonja Viljamaa for their help in the field, and to Maja Sandström, Vanessa Messinger, and Sinikka Sorsa for their assistance in the laboratory. This study was financed by the Centre for Environmental Research (CMF) in Umeå.

Open Access This article is distributed under the terms of the Creative Commons Attribution 4.0 International License (http:// creativecommons.org/licenses/by/4.0/), which permits unrestricted use, distribution, and reproduction in any medium, provided you give appropriate credit to the original author(s) and the source, provide a link to the Creative Commons license, and indicate if changes were made.

\section{References}

Bandau F, Decker VHG, Gundale MJ, Albrectsen BR (2015) Genotypic tannin levels in Populus tremula impact the way nitrogen enrichment affects growth and allocation responses for some traits and not for others. PLoS One 10:e0140971
Barbehenn RV, Constabel CP (2011) Tannins in plant-herbivore interactions. Phytochemistry 72:1551-1565

Benoit RE, Starkey RL (1968) Enzyme inactivation as a factor in inhibition of decomposition of organic matter by tannins. Soil Sci 105:203-208

Bobbink R, Hornung M, Roelofs JGM (1998) The effects of airborne nitrogen pollutants on species diversity in natural and semi-natural European vegetation. J Ecol 86:717-738

Bobbink R, Hicks K, Galloway J, Spranger T, Alkemade R, Ashmore M, Bustamante M, Cinderby S, Davidson E, Dentener F, Emmett B, Erisman JW, Fenn M, Gilliam F, Nordin A, Pardo L, De Vries W (2010) Global assessment of nitrogen deposition effects on terrestrial plant diversity: a synthesis. Ecol Appl 20:30-59

Chomel M, Guittonny-Larcheveque M, DesRochers A, Baldy V (2015) Home field advantage of litter decomposition in pure and mixed plantations under boreal climate. Ecosystems 18: 1014-1028

Cornwell WK, Cornelissen JHC, Amatangelo K, Dorrepaal E, Eviner VT, Godoy O, Hobbie SE, Hoorens B, Kurokawa H, Perez-Harguindeguy N, Quested HM, Santiago LS, Wardle DA, Wright IJ, Aerts R, Allison SD, van Bodegom P, Brovkin V, Chatain A, Callaghan TV, Diaz S, Garnier E, Gurvich DE, Kazakou E, Klein JA, Read J, Reich PB, Soudzilovskaia NA, Vaieretti MV, Westoby M (2008) Plant species traits are the predominant control on litter decomposition rates within biomes worldwide. Ecol Lett 11:10651071

De Vries W, Reinds GJ, Gundersen P, Sterba H (2006) The impact of nitrogen deposition on carbon sequestration in European forests and forest soils. Glob Chang Biol 12:1151-1173

Donaldson JR, Kruger EL, Lindroth RL (2006) Competition- and resource-mediated tradeoffs between growth and defensive chemistry in trembling aspen (Populus tremuloides). New Phytol 169:561-570

Driebe EM, Whitham TG (2000) Cottonwood hybridization affects tannin and nitrogen content of leaf litter and alters decomposition. Oecologia 123:99-107

Field A (2009) Discovering statistics using SPSS. SAGE Publications Ltd London

Fierer N, Schimel JP, Cates RG, Zou JP (2001) Influence of balsam poplar tannin fractions on carbon and nitrogen dynamics in Alaskan taiga floodplain soils. Soil Biol Biochem 33:1827-1839

Galloway JN, Townsend AR, Erisman JW, Bekunda M, Cai ZC, Freney JR, Martinelli LA, Seitzinger SP, Sutton MA (2008) Transformation of the nitrogen cycle: recent trends, questions, and potential solutions. Science 320:889-892

Garnier E, Navas M-L (2012) A trait-based approach to comparative functional plant ecology: concepts, methods and applications for agroecology. A review. Agron Sustain Dev 32: 365-399

Glynn C, Herms DA, Egawa M, Hansen R, Mattson WJ (2003) Effects of nutrient availability on biomass allocation as well as constitutive and rapid induced herbivore resistance in poplar. Oikos 101:385-397

Gundale MJ, Sverker J, Albrectsen BR, Nilsson MC, Wardle DA (2010) Variation in protein complexation capacity among and within six plant species across a boreal forest chronosequence. Plant Ecol 211:253-266 
Gundale MJ, Deluca TH, Nordin A (2011) Bryophytes attenuate anthropogenic nitrogen inputs in boreal forests. Glob Chang Biol 17:2743-2753

Gundale MJ, From F, Bach LH, Nordin A (2014) Anthropogenic nitrogen deposition in boreal forests has a minor impact on the global carbon cycle. Glob Chang Biol 20:276-286

Hagerman AE. (2002a). The Tannin Handbook; Determination of degree of polymerization - HPLC of phloroglucinol derivatives. http://www.users.miamioh.edu/hagermae/ Determination $\% 20$ of $\% 20$ Degree $\% 20$ of $\% 20$ Polymerization. pdf, retrieved 08-Mar-2015.

Hagerman AE. (2002b). The Tannin Handbook; Sephadex LH 20. http://www.users.miamioh.edu/hagermae/Sephadex\% 20LH\%2020.pdf, retrieved 08-Mar-2015.

Harding SA, Jarvie MM, Lindroth RL, Tsai C-J (2009) A comparative analysis of phenylpropanoid metabolism, $\mathrm{N}$ utilization, and carbon partitioning in fast- and slow-growing Populus hybrid clones. J Exp Bot 60:3443-3452

Helrich K (ed) (1990) Official Methods of Analysis. Association of Official Analytical Chemists, Arlington, pp. 82-83

Hemming JDC, Lindroth RL (1999) Effects of light and nutrient availability on aspen: growth, phytochemistry, and insect performance. J Chem Ecol 25:1687-1714

Herms DA, Mattson WJ (1992) The dilemma of plants - to grow or defend. Q Rev Biol 67:283-335

Holeski LM, Vogelzang A, Stanosz G, Lindroth RL (2009) Incidence of Venturia shoot blight in aspen (Populus tremuloides Michx.) varies with tree chemistry and genotype. Biochem Syst Ecol 37:139-145

Jackson BG, Peltzer DA, Wardle DA (2013) The within-species leaf economic spectrum does not predict leaf litter decomposability at either the within-species or whole community levels. J Ecol 101:1409-1419

Janssens IA, Dieleman W, Luyssaert S, Subke JA, Reichstein M, Ceulemans R, Ciais P, Dolman AJ, Grace J, Matteucci G, Papale D, Piao SL, Schulze ED, Tang J, Law BE (2010) Reduction of forest soil respiration in response to nitrogen deposition. Nat Geosci 3:315-322

Joanisse GD, Bradley RL, Preston CM, Munson AD (2007) Soil enzyme inhibition by condensed litter tannins may drive ecosystem structure and processes: the case of Kalmia angustifolia. New Phytol 175:535-546

King JS, Pregitzer KS, Zak DR, Kubiske ME, Holmes WE (2001) Correlation of foliage and litter chemistry of sugar maple, Acer saccharum, as affected by elevated $\mathrm{CO}_{2}$ and varying $\mathrm{N}$ availability, and effects on decomposition. Oikos 94:403-416

Knops JMH, Reinhart K (2000) Specific leaf area along a nitrogen fertilization gradient. Am Midl Nat 144:265-272

Knorr M, Frey SD, Curtis PS (2005) Nitrogen additions and litter decomposition: A meta-analysis. Ecology 86:3252-3257

Kouki J, Arnold K, Martikainen P (2004) Long-term persistence of aspen - a key host for many threatened species - is endangered in old-growth conservation areas in Finland. J Nat Conserv 12:41-52

Kraus TEC, Dahlgren RA, Zasoski RJ (2003) Tannins in nutrient dynamics of forest ecosystems - a review. Plant Soil 256:4166

Kumordzi BB, Nilsson M-C, Gundale MJ, Wardle DA (2014) Changes in local-scale intraspecific trait variability of dominant species across contrasting island ecosystems. Ecosphere 5: art 26
LeRoy CJ, Whitham TG, Wooley SC, Marks JC (2007) Withinspecies variation in foliar chemistry influences leaf-litter decomposition in a Utah river. J N Am Benthol Soc 26: 426- 438

LeRoy CJ, Wooley SC, Lindroth RL (2012) Genotype and soil nutrient environment influence aspen litter chemistry and instream decomposition. Freshw Sci 31:1244-1253

Lindkvist A, Kardell O, Nordlund C (2011) Intensive forestry as progress or decay? An analysis of the debate about forest fertilization in Sweden, 1960-2010. Forests 2:112-146

Lindroth RL, Hwang SY (1996) Clonal variation in foliar chemistry of quaking aspen (Populus tremuloides Michx). Biochem Syst Ecol 24:357-364

Liu L, King JS, Giardina CP, Booker FL (2009) The influence of chemistry, production and community composition on leaf litter decomposition under elevated atmospheric $\mathrm{CO}_{2}$ and tropospheric $\mathrm{O}_{3}$ in a northern hardwood ecosystem. Ecosystems 12:401-416

Luquez V, Hall D, Albrectsen BR, Karlsson J, Ingvarsson P, Jansson S (2008) Natural phenological variation in aspen (Populus tremula): the SwAsp collection. Tree Genet Genomes 4:279-292

Maaroufi NI, Nordin A, Hasselquist NJ, Bach LH, Palmqvist K, Gundale MJ (2015) Anthropogenic nitrogen deposition enhances carbon sequestration in boreal soils. Glob Chang Biol 21:3169-3180

Madritch MD, Hunter MD (2002) Phenotypic diversity influences ecosystem functioning in an oak sandhills community. Ecology 83:2084-2090

Madritch MD, Hunter MD (2005) Phenotypic variation in oak litter influences short- and long-term nutrient cycling through litter chemistry. Soil Biol Biochem 37:319-327

Madritch MD, Lindroth RL (2015) Condensed tannins increase nitrogen recovery by trees following insect defoliation. New Phytol 208:410-420

Madritch M, Donaldson JR, Lindroth RL (2006) Genetic identity of Populus tremuloides litter influences decomposition and nutrient release in a mixed forest stand. Ecosystems 9:528537

Madritch MD, Donaldson JR, Lindroth RL (2007a) Canopy herbivory can mediate the influence of plant genotype on soil processes through frass deposition. Soil Biol Biochem 39: 1192-1201

Madritch MD, Jordan LM, Lindroth RL (2007b) Interactive effects of condensed tannin and cellulose additions on soil respiration. Can J For Res 37:2063-2067

Madritch MD, Kingdon CC, Singh A, Mock KE, Lindroth RL, Townsend PA (2014) Imaging spectroscopy links aspen genotype with below-ground processes at landscape scales. Philos Trans R Soc Lond, Ser B: Biol Sci 369: art 20130194

Meunier CL, Gundale MJ, Sanchez IS, Liess A (2016) Impact of nitrogen deposition on forest and lake food webs in nitrogen-limited environments. Glob Chang Biol 22:164-179

Nikula S, Vapaavuori E, Manninen S (2010) Urbanization-related changes in European aspen (Populus tremula L.): leaf traits and litter decomposition. Environ Pollut 158:2132-2142

Nordin A, Nasholm T, Ericson L (1998) Effects of simulated N deposition on understorey vegetation of a boreal coniferous forest. Funct Ecol 12:691-699 
Nordin A, Strengbom J, Witzell J, Nasholm T, Ericson L (2005) Nitrogen deposition and the biodiversity of boreal forests: implications for the nitrogen critical load. Ambio 34:20-24

Nordin A, Strengbom J, Ericson L (2006) Responses to ammonium and nitrate additions by boreal plants and their natural enemies. Environ Pollut 141:167-174

Osier TL, Lindroth RL (2006) Genotype and environment determine allocation to and costs of resistance in quaking aspen. Oecologia 148:293-303

Parsons WFJ, Bockheim JG, Lindroth RL (2008) Independent, interactive, and species-specific responses of leaf litter decomposition to elevated $\mathrm{CO}_{2}$ and $\mathrm{O}_{3}$ in a northern hardwood forest. Ecosystems 11:505-519

Porter LJ, Hrstich LN, Chan BG (1986) The conversion of procyanidins and prodelphinidins to cyanidin and delphinidin. Phytochemistry 25:223-230

Prescott CE (2010) Litter decomposition: what controls it and how can we alter it to sequester more carbon in forest soils? Biogeochemistry 101:133-149

Randriamanana TR, Nybakken L, Lavola A, Aphalo PJ, Nissinen K, Julkunen-Tiitto R (2014) Sex-related differences in growth and carbon allocation to defence in Populus tremula as explained by current plant defence theories. Tree Physiol 34:471-487

Robinson KM, Ingvarsson PK, Jansson S, Albrectsen BR (2012) Genetic variation in functional traits influences arthropod community composition in aspen (Populus tremula L.). PLoS One 7:e37679

Schweitzer JA, Bailey JK, Rehill BJ, Martinsen GD, Hart SC, Lindroth RL, Keim P, Whitham TG (2004) Genetically based trait in a dominant tree affects ecosystem processes. Ecol Lett 7:127-134

Schweitzer JA, Madritch MD, Bailey JK, LeRoy CJ, Fischer DG, Rehill BJ, Lindroth RL, Hagerman AE, Wooley SC, Hart SC, Whitham TG (2008) From genes to ecosystems: the genetic basis of condensed tannins and their role in nutrient regulation in a Populus model system. Ecosystems 11:1005-1020

Siitonen J, Martikainen P (1994) Occurrence of rare and threatened insects living on decaying Populus tremula - a comparison between Finnish and Russian Karelia. Scand J For Res 9:185-191

Silfver T, Mikola J, Rousi M, Roininen H, Oksanen E (2007) Leaf litter decomposition differs among genotypes in a local Betula pendula population. Oecologia 152:707-714
Silfver T, Paaso U, Rasehorn M, Rousi M, Mikola J (2015) Genotype $\mathrm{x}$ herbivore effect on leaf litter decomposition in Betula pendula saplings: ecological and evolutionary consequences and the role of secondary metabolites. PLoS One 10: $\mathrm{e} 0116806$

Stamp N (2003) Out of the quagmire of plant defense hypotheses. Q Rev Biol 78:23-55

Stark S, Mannisto MK, Eskelinen A (2014) Nutrient availability and $\mathrm{pH}$ jointly constrain microbial extracellular enzyme activities in nutrient-poor tundra soils. Plant Soil 383:373-385

Stevens MT, Lindroth RL (2005) Induced resistance in the indeterminate growth of aspen (Populus tremuloides). Oecologia 145:298-306

Strengbom J, Walheim M, Nasholm T, Ericson L (2003) Regional differences in the occurrence of understorey species reflect nitrogen deposition in Swedish forests. Ambio 32:91-97

Sundqvist MK, Giesler R, Wardle DA (2011) Within- and acrossspecies responses of plant traits and litter decomposition to elevation across contrasting vegetation types in subarctic tundra. PLoS One 6:e27056

Sundqvist MK, Wardle DA, Olofsson E, Giesler R, Gundale MJ (2012) Chemical properties of plant litter in response to elevation: subarctic vegetation challenges phenolic allocation theories. Funct Ecol 26:1090-1099

Talbot JM, Yelle DJ, Nowick J, Treseder KK (2012) Litter decay rates are determined by lignin chemistry. Biogeochemistry 108:279-295

Tamm CO (1991) Nitrogen in terrestrial ecosystems: questions of productivity, vegetational changes, and ecosystem stability. Springer-Verlag, Berlin Heidelberg

Updegraff DM (1969) Semimicro determination of cellulose in biological materials. Anal Biochem 32:420-424

Vitousek PM, Howarth RW (1991) Nitrogen limitation on land and in the sea - how can it occur. Biogeochemistry 13:87-115

Wardle DA, Bardgett RD, Walker LR, Bonner KI (2009) Amongand within-species variation in plant litter decomposition in contrasting long-term chronosequences. Funct Ecol 23:442453

Wardle DA, Jonsson M, Bansal S, Bardgett RD, Gundale MJ, Metcalfe DB (2012) Linking vegetation change, carbon sequestration and biodiversity: insights from island ecosystems in a long-term natural experiment. J Ecol 100:16-30

Zhang DQ, Hui DF, Luo YQ, Zhou GY (2008) Rates of litter decomposition in terrestrial ecosystems: global patterns and controlling factors. J Plant Ecol 1:85-93 